\title{
STRATEGI PENGEMBANGAN PRODUK PEMBIAYAAN DALAM UPAYA PENINGKATAN KAPASITAS UMKM PADA BPRS UMMU DI BANGIL PASURUAN
}

\author{
Nila Safira Ramadhanty \\ Fakultas Agama Islam, Universitas Muhammadiyah Sidoarjo \\ Email: nilasafira2398@gmail.com \\ Renny Oktafia \\ Fakultas Agama Islam, Universitas Muhammadiyah Sidoarjo \\ Email: renny.oktafia@umsida.ac.id
}

\begin{abstract}
This study aims to determine the strategy of developing financing products in an effort to increase the capacity of micro, small and medium enterprises (MSMEs) at Islamic people's financing bank (BPRS) UMMU in Bangil Pasuruan. This type of research uses qualitative methods. Data sources used in this study are primary data and secondary data. Data collection techniques used were interviews and documentation. The results of this study ate the existence of BPRS UMMU in Bangil Pasuruan is very beneficial for the community especially thosr who have small an medium micro businesses because with the financing can help in terms of capital, increase the capacity to trade and help sustain the economy in Bangil Pasuruan.
\end{abstract}

Keywords: Financing, BPRS, MSMEs

\section{Abstrak}

Penelitian ini bertujuan untuk mengetahui strategi pengembangan produk pembiayaan dalam upaya peningkatan kapasitas Usaha Mikro, Kecil dan Menengah (UMKM) pada Bank Pembiayaan Rakyat Syariah (BPRS) UMMU di Bangil Pasuruan. Jenis penelitian ini menggunakan metode kualitatif. Sumber data yang digunakan dalam penelitian ini adalah data primer dan data sekunder. Teknik pengumpulan data yang digunakan adalah wawancara dan dokumentasi. Hasil penelitian ini adalah keberadaan BPRS UMMU di Bangil Pasuruan sangat bermanfaat bagi masyarakat khususnya yang mempunyai usaha mikro kecil menengah karena dengan adanya pembiayaan dapat membantu dari segi permodalan, meningkatkan kemampuan berdagang dan membantu menopang perekonomian di Bangil Pasuruan.

Kata Kunci: Pembiayaan, BPRS, UMKM.

\section{Dasar Pemikiran}

Bank syariah pertama di Indonesia yaitu Bank Muamalat yang berdiri pada tanggal 1 November 1991 sebelum lahirnya Undang-Undang Nomor 7 Tahun 1992 yang memungkinkan berdiriya bank dengan melakukan kegiatan usahanya berlandaskan prinsip syariah (Syahreni, 2014). Akan tetapi mulai beroperasinya Bank Muamalat P-ISSN : 2460-9595 
Indonesia (BMI) ini pada tanggal 1 Mei 1992. Keberadaan BMI semakin diperkuat dengan munculnya Undang-Undang No. 7 Tahun 1992 secara konstitusi tentang Perbankan, yang mana perbankan bagi hasil diakomodasi. Dalam UU tersebut, pasal 13 ayat (c) menyatakan bahwasanya salah satu usaha Bank Perkreditan Rakyat (BPR) menyediakan Pembiayaan bagi nasabah berdasarkan prinsip bagi hasil sesuai dengan ketentuan yang ditetapkan dalam peraturan pemerintah. Menanggapi Pasal tersebut, pada tanggal 30 Oktober 1992 pemerintah sudah mengeluarkan Peraturan Pemerintah (PP) No. 7 tahun 1992 terkait bank berdasarkan prinsip bagi hasil dan diundangkan pada tanggal 30 Oktober 1992 dalam lembaga negara Republik Indonesia (Iska, 2012).

Berdirinya BMI yang di dalam kegiatan usahanya menggunakan prinsip sesuai syariah Islam, kemudian mulai banyak bermunculan lembaga keuangan syariah lainnnya, seperti Bank Syariah Mandiri (BSM), Bank BNI Syariah, Bank Pembiayaan Rakyat Syariah (BPRS) dan sebagainya. Dengan adanya lembaga keuangan syariah tersebut diharapkan mampu menjangkau masyarakat mulai dari golongan paling bawah sampai dengan golongan paling atas guna untuk mengenal serta memanfaatkan jasa lembaga keuangan syariah (Wiroso, 2005).

Seiring dengan perkembangan industri perbankan Syariah di Indonesia khususnya Bank Pembiayaan Rakyat Syariah (BPRS) sekarang menjadi lembaga keuangan yang sangat dibutuhkan oleh masyarakat terutama yang mempunyai usaha untuk membantu dalam hal permodalan (Darsono, 2017). Berdirinya Bank Pembiayaan Rakyat Syariah (BPRS) di Indonesia selain didasari oleh tuntutan bermuamalah secara Islam yang tidak lain merupakan keinginan terkuat di Indonesia dari sebagian besar Umat Islam, serta didasari juga oleh perekonomian di Indonesia yang dituangkan dalam berbagai kebijaksanaan keuangan, moneter dan perbankan secara umum. Adapun secara khususnya yaitu mengisi peluang terhadap kebijaksanaan yang membebaskan bank dalam penetapan tingkat suku bunga (Rate Interest), yang kemudian dikenal dengan bank tanpa bunga atau bisa dikatakan tanpa riba (Darsono, 2017).

Seperti yang telah diketahui bersama, bahwasanya riba merupakan suatu larangan bukan hanya oleh Fatwa-fatwa DSN-MUI, akan tetapi karena adanya firman Allah yang 
sering kali menyebutkan terkait riba, seperti dalam Qur'an Surah Al-Baqarah ayat 276 yang berbunyi :

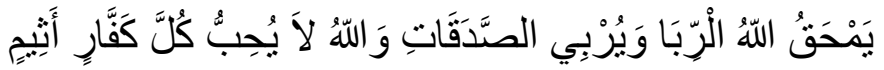

Artinya: "Allah memusnahkan riba dan menyuburkan sedekah, Allah tidak menyukai setiap orang yang tetap dalam kekafiran dan bergelimang dosa"(Al-Qur'an, 2019).

Sebagaimana yang telah dijelaskan dalam ayat suci Al-Qur'an dan Hadits di atas bahwasanya Allah melarang melakukan sesuatu hal yang terkait dengan riba. Dan salah satu lembaga keuangan syariah yang ikut andil dalam perbankan syariah berdasarkan prinsip syariah dan terlepas dari bunga atau riba dalam usahanya adalah Bank Pembiayaan Rakyat Syariah (BPRS).

Keberadaan Bank Pembiayaan Rakyat Syariah (BPRS) dalam sistem perbankan Indonesia merupakan bank umum yang berlandaskan pada prinsip syariah, prinsip syariah diartikan sebagai aturan perjanjian berdasarkan hukum Islam antara bank dan pihak lain untuk penyimpanan dana dan pembiayaan kegiatan usaha atau kegiatan lainnya yang dinyatakan sesuai dengan syariah, antara lain pembiayaan berdasarkan prinsip bagi hasil (mudharabah), pembiayaan berdasarkan prinsip penyertaan modal (musyarakah), atau prinsip jual beli barang dengan memperoleh keuntungan (murabahah) (Darsono, 2017).

Berikut ini Data OJK dalam Statistik Perbankan Syariah (SPS) mengenai komposisi pembiayaan yang diberikan Bank Pembiayaan Rakyat Syariah (BPRS) yang akurat serta terbaru di Tahun 2019 yang diakses pada tanggal 7 Juli 2020.

\section{Tabel 1. Komposisi Pembiayaan Yang Diberikan}

Bank Pembiayaan Rakyat Syariah 2019

\begin{tabular}{|c|c|c|c|c|}
\hline Akad & Januari & Februari & Maret & April \\
\hline $\begin{array}{c}\text { Akad } \\
\text { Mudharabah }\end{array}$ & 220.048 & 196.986 & 249.179 & 269.051 \\
\hline $\begin{array}{c}\text { Akad } \\
\text { Musyarakah }\end{array}$ & 1.135 .809 & 1.073 .291 & 1.198 .255 & 1.214 .672 \\
\hline $\begin{array}{c}\text { Akad } \\
\text { Murabahah }\end{array}$ & 7.711 .400 & 7.854 .630 & 7.912 .797 & 7.849 .489 \\
\hline
\end{tabular}

DOI. 10.36908/isbank 
202 | Nila Safira Ramadhanty, Renny Oktafia, STRATEGI PENGEMBANGAN PRODUK..........

\begin{tabular}{|c|c|c|c|c|}
\hline TOTAL & 9.067.257 & 9.124.907 & 9.360.231 & 9.333.212 \\
\hline
\end{tabular}

Sumber: Statistik Perbankan Syariah, April 2020

Dengan produk beragam yang berada di Bank Pembiayaan Rakyat Syariah (BPRS) dan bisa disesuaikan dengan kebutuhan masyarakat diharapkan bisa membantu sektorsektor yang kecil. Seperti yang telah kita ketahui bahwa perekonomian Indonesia ini sangat dipengaruhi oleh sektor tersebut atau yang lebih kita kenal dengan usaha mikro, kecil dan menengah (UMKM). Sekilas kita melihat pada sejarah ekonomi Indonesia pada tahun 1997 di mana pada waktu itu terjadi krisis yang sangat menakutkan bagi perekonomian Indonesia. Usaha-usaha besar saat itu satu persatu mengalami pailit dan tidak mampu meneruskan usaha karena tingkat suku bunga yang tinggi, berbeda dengan UMKM yang saat itu tetap bertahan bahkan cenderung bertambah.

Bank Pembiayaan Rakyat Syariah (BPRS) UMMU di Bangil termasuk salah satu Bank Pembiayaan Rakyat Syariah yang menjalankan pengembangan produk pembiayaan diantaranya pembiayaan mudharabah, musyarakah dan murabahah. BPRS UMMU bertujuan untuk membantu masyarakat yang memiliki usaha-usaha mikro, kecil dan menengah. BPRS UMMU ini merupakan BPRS yang tumbuh di wilayah bangil pasuruan yang beroperasi berdasarkan prinsip-prinsip syariah Islam yang bertujuan di antaranya menumbuhkan ekonomi masyarakat atas dasar syariah Islam.

\section{Rumusan Masalah}

1. Bagaimana strategi pengembangan produk pembiayaan dalam upaya peningkatan kapasitas Usaha Mikro Kecil dan Menengah (UMKM) pada BPRS UMMU di Bangil Pasuruan?

2. Apa dampak bagi nasabah yang memiliki Usaha Mikro Kecil dan Menengah (UMKM) dengan adanya produk pembiayaan pada BPRS UMMU di Bangil Pasuruan? 
ISLAMIC BANKING: Jurnal Pemikiran dan Pengembangan Perbankan Syariah, Volume 6 Nomor 2 Edisi Februari 2021

\section{Tinjauan Pustaka}

\section{Strategi}

Menurut Mintzberg strategi merupakan suatu cara dalam mempromosikan produk tertentu ke pasar yang telah dituju. Strategi biasanya cenderung melihat ke bawah, yaitu pada suatu titik bidik, yang mana produk tertentu bertemu dengan pelanggan, serta melihat keluar yaitu dengan meninjau berbagai aspek pada lingkungan eksternal. Strategi ialah alat untuk mencapai suatu tujuan. Pada perkembangannya, konsep terkait dengan strategi terus berkembang. Dalam hal ini dapat ditujukan oleh adanya perbedaan konsep mengenai strategi selama 30 tahun terakhir (Rangkuti, 1997).

\section{Pengembangan Produk}

Pengembangan produk adalah suatu proses dari pencarian ide-ide untuk barangbarang dan pelayanan-pelayanan baru, dan mengubahnya menjadi tambahan lain produk yang berhasil secara komersil. Alasan dasar perusahaan mengembangkan produk baru adalah untuk menggantikan item-item yang telah kehilangan minat dari konsumen. Pengenalan item baru membantu meningkatkan pendapatan dan keuntungan bagi perusahaan (Haris, 2017).

Seorang ahli, Assury mengatakan tentang pengertian pengembangan produk ialah suatu aktifitas reproduksi terhadap produk yang lebih baik agar meningkatkan daya pakai dan peningkatan terhadap produk yang memuskan. Staton juga pernah memberikan pengertian tentang pengembangan produk, yaitu terfokus kepada aktifitas yang berdominan kepada bidang teknis nya, seperti investigasi produk, perancangan produk dan memperhitungkan segala fungsi, estetika produk. Guiltinan juga berkata, bahwa yang dimaksud pengembangan produk ialah adanya sebuah daya saing dan perubahan teknologi yang mengakibatkan sebuah kebutuhan dan keinginan. Menurut sigit ialah sebuah kegiatan reproduksi produk sebagai penyesuaian terhadap penawaran dan penjualan atas keinginan konsumen. Armstrong dan Kotler memberi istilah yaitu strategi pengembangan produk adalah bagian dari promosi kepada pasar-pasar untuk pertumbuhan perusahaan (Tjiptono, 2017). 


\section{4 | Nila Safira Ramadhanty, Renny Oktafia, STRATEGI PENGEMBANGAN PRODUK..........}

Dapat disimpulkan dari berbagai penjelasan yang dikemukakan oleh para ahli diatas, bahwa yang dimaksud pengembangan produk adalah sebuah usaha yang dilakukan oleh sebuah perusahaan untuk meningkatkan kualitas produk nya dan daya jual saing untuk kepuasan para pelanggan atau konsumen

\section{Pembiayaan}

Pembiayaan secara istilah adalah suatu pemberian dana yang diberikan oleh instansi keuangan. Adapun secara istilah adalah suatu pemberian dana yang dilakukan oleh pihak 1 kepada pihak 2 dalam mensupport investasi yang telah direncanakan. Pengertian pembiayaan didalam bank konvensional lebih dikenal dengan sebuah istilah kredit (Aravik, 2021). Kredit ialah ketersediaan uang atau tagihan yang bisa diperbandingkan dengan itu, atas dasar persetujuan atau kesepakatan pinjam meminjam mengembalikan pinjamannya setelah batas waktu yang disediakan yang disertakan bunga (Soemitra, 2016).

Sedangkan pembiayaan berdasarkan prinsip syariah menurut Peraturan Bank Indonesia ialah tagihan atau penyediaan uang berdasarkan kesepakatan atau persetujuan yang dipersamakan dengan itu baik antara bank dengan pihak lain yang mewajibkan pihak yang dibiayai dengan imbalan atau bagi hasil. Pembiayaan yang disamakan dengan kredit yang berdasarkan dengan prinsip syariah ialah penyediaan uang atau tagihan yang bisa dipersamakan dengan itu berdasarkan dengan kesepakatan atau persetujuan pinjam meminjam antara bank dengan pihak lain diwajibkan kepada pihak peminjam untuk melunasi hutangnya dengan pemberian bagi hasil atau imbalan setelah jangka waktu yang sudah ditentukan.

\section{Usaha Mikro Kecil dan Menengah (UMKM)}

UMKM merupakan singkatan dari Usaha Mikro, Kecil dan Menengah. UMKM diatur berdasarkan UU No. 20 Tahun 2008 tentang Usaha Mikro, Kecil dan Menengah. Dalam undang-undang tersebut dijelaskan bahwa sebuah perusahaan yang digolongkan sebagai UMKM adalah perusahaan kecil yang dimiliki dan dikelola oleh seseorang atau dimiliki oleh sekelompok kecil orang dengan jumlah kekayaan dan pendapatan tertentu. 
Di Indonesia, Usaha Mikro Kecil dan Menengah sering disingkat menjadi (UMKM), UMKM saat ini dianggap sebagai cara yang efektif dalam mengetaskan kemiskinan. Dari statistik dan riset yang dilakukan, UMKM mewakili jumlah kelompok usaha terbesar. UMKM merupakan kelompok pelaku terbesar dalam perekonomian Indonesia dan sudah terbukti menjadi pengaman perekonomian nasional dalam masa krisis, serta menjadi dinamisator pertumbuhan ekonomi pasca krisis ekonomi. Selain menjadi sektor usaha yang paling besar kontribusinya terhadap pembangunan nasional. UMKM juga menciptakan peluang kerja yang cukup besar bagi tenaga kerja dalam negeri, sehingga membantu upaya mengurangi pengangguran (Partono \& Soejono, 2002).

\section{Bank Pembiayaan Rakyat Syariah (BPRS)}

Bank Pembiayaan Rakyat Syariah (BPRS) merupakan bank di dalam kegiatan usahanya melaksanakan berlandaskan prinsip-prinsip syariah dan dalam kegiatan usahanya tidak memberikan jasa dalam lalu lintas pembayaran. Berdirinya Bank Pembiayaan Rakyat Syariah (BPRS) berdasarkan UU No. 7 Tahun 1992 tentang Perbankan dan Peraturan Pemerintah (PP) No. 7 Tahun 1992 tentang Bank berdasarkan prinsip bagi hasil. Pada pasal 1 (butir 4) UU No. 10 Tahun 1998 tentang Perubahan atas UU No. 7 Tahun 1992 tentang Perbankan dijelaskan bahwasanya BPRS adalah bank yang di dalam kegiatan usahanya melaksanakan berdasarkan prinsip syariah yang tidak memberikan jasa dalam lalu lintas pembayaran dalam kegiatannya.

Undang-Undang No. 12 Tahun 2008 tentang Bank Syariah secara khusus sudah mengatur eksistensi Bank Syariah di Indonesia. Undang-undang tersebut menyempurnakan serta melengkapi UU Nomor 10 Tahun 1998 yang belum terlengkapi. Bank syariah menurut Pasal 18 Undang-Undang Nomor 21 Tahun 2008 terdiri dari Bank Syariah serta Bank Pembiayaan Rakyat Syariah. Seluruh peraturan perundangundangan yang menyebut BPRS dengan sebutan Bank Perkreditan Rakyat Syariah berganti dengan Bank Pembiayaan Rakyat Syariah karena BPRS dalam kegiatan usahanya menggunakan prinsip-prinsip Islam (Susanto, 2008). 
206 | Nila Safira Ramadhanty, Renny Oktafia, STRATEGI PENGEMBANGAN PRODUK..........

\section{Metode Penelitian}

\section{Jenis Penelitian}

Metode penelitian yang digunakan peneliti merupakan metode penelitian kualitatif. Metode penelitian kualitatif adalah penelitian yang bermaksud untuk memahami fenomena tentang apa yang dialami oleh subyek penelitian misalkan perilaku, persepsi, motivasi, tindakan dan lain-lain secara holistik, dan dengan cara deskripsi dalam bentuk kata-kata dan bahasa, pada suatu konteks khusus yang alamiah dan dengan memanfaatkan berbagai metode alamiah (Moelong, 2016).

\section{Tempat Penelitian}

Peneliti melakukan penilitian di PT BPRS UMMU Bangil untuk mendapatkan data tentang pembiayaan Bank Pembiayaan Rakyat Syariah (BPRS) dalam mengembangkan Usaha Mikro Kecil dan Menengah (UMKM). Penelitian dilakukan hanya disatu perusahaan, karena ingin mendapatkan hasil yang maksimal untuk memenuhi data yang dibutuhkan. Alasan memilih BPRS dalam pembiayaan untuk pengembangan UMKM karena ditempat yang peneliti ketahui BPRS tersebut dekat sekali dengan pasar.

Alamat : Jl. Mangga No. 857 Kec. Bangil Kab. Pasuruan.

No. Telp : (0343) 742218

\section{Sumber Data}

Sumber data dalam penelitian ini diambil dari sumber data primer dan sumber data sekunder.

1. Sumber Data Primer

Data Primer adalah data yang didapatkan dari sumber pertama baik dari individu atau perseorangan, seperti hasil wawancara atau suatu pengisian hasil kuisioner (Umar, 2008).

2. Sumber Data Sekunder

Data sekunder merupakan sumber data yang diberikan tidak secara langsung kepada pengumpul data atau peneliti, melainkan dikumpulkan lewat orang lain ataupun dokumen pendukung lain. Data sekunder juga diperoleh dari referensi 
ISLAMIC BANKING: Jurnal Pemikiran dan Pengembangan Perbankan Syariah, Volume 6 Nomor 2 Edisi Februari 2021

pustaka yang menjadi bahan acuan dalam penelitian atau dari hasil pemikiran lainnya (Sugiyono, 2018).

\section{Teknik Pengumpulan Data}

Adapun teknik pengumpulan data yang digunakan peneliti adalah sebagai berikut:

1. Wawancara

Teknik wawancara yang dipilih oleh peneliti adalah wawancara terstruktur yaitu sebagai teknik pengumpulan data apabila peneliti atau pengumpul data sudah menyiapkan informasi apa yang akan diperoleh peneliti berupa pertanyaan dan pilihan alternatif jawaban. Wawancara terstruktur memberikan pertanyaan yang sama kebeberapa responden, sehingga peneliti harus memiliki instrumen pedoman untuk pertanyaan yang akan diberikan kepada narasumber (Suharsaputra, 2014).

2. Dokumentasi

Dokumentasi adalah kumpulan dari seluruh fakta dan data dari suatu peristiwa yang sudah berlalu, tersimpan dalam bentuk teks ataupun naskah penelitian terdahulu (Musfiqon, 2012). Teknik pengumpulan data dokumentasi adalah pelengkap daripada metode wawancara dengan cara mengumpulkan data melalui foto dan gambar hasil penelitian, jurnal, buku dan penelitian sejenis lainnya (Sugiyono, 2018).

\section{Hasil dan Pembahasan}

\section{Sejarah PT. Bank Pembiayaan Rakyat Syariah (BPRS)}

Bank Pembiayaan Rakyat Syariah (BPRS) merupakan bank syariah yang saham terbesarnya dimiliki oleh Koperasi BMT UGT Sidogiri dan Koperasi BMT Maslahah. Dulunya bernama Koperasi Bank Perkreditan Rakyat (KBPR) Untung Surapati. Setelah saham terbesarnya dimiliki oleh Koperasi BMT UGT Sidogiri dan Koperasi BMT Maslahah namanya diganti menjadi PT. Bank Pembiayaan Rakyat Syariah BPRS UMMU dan mengganti bank konvensional menjadi bank syariah.dengan motto Memelihara Amanah Meraih Barokah PT. BPR Syariah UMMU bertekad untuk memberikan layanan bank syariah terbaik kepada masyarakat. Perubahan dari sistem 


\section{8}

Nila Safira Ramadhanty, Renny Oktafia, STRATEGI PENGEMBANGAN PRODUK..........

konvensional membawa berkah sehingga berhasil bangkit dari bank yang merugi menjadi bank yang beruntung. Perkembangan kinerja keuangan PT. BPR Syariah UMMU yang makin baik setelah ditangani oleh manajemen dari Koperasi BMT UGT Sidogiri dan Koperasi BMT Maslahah menghapus sejarah kelam masa lalu saat masih bernama Koperasi Bank Perkreditan Rakyat (KBPR).

Melongok ke masa lalu, awalnya dulu bernama Koperasi Bank Perkreditan Rakyat (KBPR) Untung Surapati yang didirikan pada tahun 1993 dengan badan hukum koperasi, berdasarkan Surat Ijin Menteri Keuangan No. KEP-161/KM.17/1993 tanggal 30 Juli 1993 dan Departemen Koperasi Wilayah Propinsi Jawa Timur No. 7503/BANGWAS-II/92. Adapun anggota koperasi pada saat itu terdiri atas 4 (empat) Koperasi yaitu : (a) KPN Pemda Kabupaten Pasuruan, (b) KPN Bakti Husada Pasuruan, (c) KPN Usber KanKop Pasuruan, dan (d) KUD Sejahtera Bangil.

Memulai usaha/operasional pada bulan Nopember 1993 sampai dengan bulan Oktober 1994 mengalami kerugian sehingga berdasarkan hasil keputusan Rapat Anggota maka sejak Nopember 1994 sampai dengan April 1995 berhenti melakukan kegiatan usaha. Selanjutnya pada bulan Februari 1995 diadakan Rapat Anggota yang bertempat di Kantor Departemen Koperasi Kabupaten Pasuruan dengan salah satu keputusannya disepakati masuknya 2 (dua) anggota Koperasi yaitu : (a) KSU Bangun Jaya dan (b) KSU Estu Kertaraharja.

Berdasarkan hasil keputusan Rapat Anggota dimaksud maka pada bulan Mei 1995 melanjutkan usahanya dengan susunan Pengurus, Badan Pemeriksa dan Direksi baru. Dalam perjalanannya dengan alasan yang bisa diterima oleh anggota maka pada Rapat Anggota Tahunan 1998 diputuskan menyetujui pengunduran diri 3 Anggota Koperasi yaitu : (a) KSU Estu Kertaraharja Pasuruan, (b) KPN Bakti Husada Pasuruan, dan (c) KUD Sejahtera Bangil.

Susunan Pengurus, Badan Pemeriksa dan Direksi tersebut di atas berjalan sampai dengan awal tahun 1999. Karena mengalami kerugian yang besar sekali maka selanjutnya pada tanggal 5 Pebruari 1999 diadakan Rapat Anggota Tahunan (RAT) dengan salah satu keputusannya menyetujui keluarnya KSU Bangun Jaya sehingga kepemilikan berubah menjadi 2 Anggota Koperasi yaitu: (a) KPN (selanjutnya berubah 
menjadi KPRI) Pemda Kabupaten Pasuruan dan (b) KPN (selanjutnya berubah menjadi KPRI).

Dengan dua anggota ini KBPR Untung Surapati Bangil sulit berkembang dikarenakan permodalan yang minim di satu sisi, disisi lain harus menyelesaikan seluruh kewajiban kepada Bank Indonesia maupun kerugian operasional yang ditinggalkan oleh manajemen lama, maka harus diupayakan untuk mencari anggota baru yang diharapkan bisa menyediakan dana (modal) untuk perkembangan KBPR Syariah Untung Surapati Bangil. Dengan berbagai usaha yang dilakukan oleh Pengurus maupun Direksi sehingga dapat menarik 4 (empat) Koperasi untuk menjadi anggota.

Selanjutnya, pada tanggal 7 Pebruari 2000 diadakan Rapat Anggota Tahunan yang salah satu keputusannya menyetujui masuknya 4 Anggota baru yaitu : (a) Koperasi BMT MMU Sidogiri Pasuruan, (b) KUD Sumber Rejeki Prigen, (c) KUD Sembada Puspo, dan (d) Kopwan Kartika Candra Pandaan.

Berangkat dari latar belakang salah satu anggota (pemilik modal mayoritas) dari pondok pesantren dan atas kesepakatan seluruh anggota yang ada dan dikaitkan dengan daerah dimana KBPR Syariah Untung Surapati berada, yaitu kota Bangil sebagai kota santri maka diputuskan untuk merubah sistem operasional dari konvensional ke sistem syariah.

Tepatnya pada tanggal 25 April 2001 mendapat Ijin Prinsip, dan pada tanggal 09 Agustus 2001 mendapat ijin Usaha dari Bank Indonesia Pusat Jakarta. Semenjak beralihnya ke sistim syariah maka terjadi perkembangan usaha yang cukup signifikan. Namun disisi permodalan anggota tidak bisa menyeimbangkan dengan kenaikan Aset yang ada sehingga sepakat mengubah badan hukum dari Koperasi ke PT (dengan dikeluarkannya Ijin Prinsip dari Bank Indonesia Malang pada tanggal 8 Februari 2005 dan ijin operasional tanggal 30 September 2005) sehingga nama KBPRS Untung Surapati berubah menjadi PT. BPRS Untung Surapati, dengan harapan agar masyarakat umum bisa turut serta memiliki saham di PT. BPRS Untung Surapati.

Pada akhir tahun 2008 PT. BPRS Untung Surapati mengalami musibah sehingga BPRS Untung Surapati ditetapkan oleh Bank Indonesia sebagai Bank yang berstatus Dalam Pengawasan Khusus (DPK) Bank Indonesia dan PT. BPRS Untung Surapati P-ISSN : 2460-9595 


\section{0 | Nila Safira Ramadhanty, Renny Oktafia, STRATEGI PENGEMBANGAN PRODUK..........}

masih mampu untuk menyelesaikannya, keluar dari musibah itu sehingga bank masih dapat beroperasional sampai saat ini dengan baik. Para pemegang saham sepakat memberi nama baru pada BPRS Untung Surapati menjadi BPRS UMMU. Nama UMMU itu sendiri artinya adalah IBU. Harapan para pemegang saham, adalah BPRS UMMU nantinya senantiasa produktif layaknya seorang IBU yang selalu produktif, dan senantiasa memberikan hawa kasih sayang kepada para mitranya, layaknya seorang ibu yang selalu memberikan kasih sayang kepada anak-anaknya. Namun, disisi lain, nama UMMU ini sebenarnya adalah gabungan dari dua nama lembaga keuangan BMT UGT dan BMT MMU Sidogiri sebagai pemegang saham terbesar dan sebagai pemegang saham pengendali. Akhirnya, dua nama lembaga besar tersebut digabung menjadi UMMU (UGT dan MMU).

Tepat pada tanggal 29 November 2011 terbitlah Surat Keputusan Direktur Perbankan Syariah Bank Indonesia Pusat nomor:13/6/kep.dir.pbs/2011 yang isinya memberikan izin usaha yang baru kepada BPRS Untung Surapati dengan nama baru yaitu: PT.BPRS UMMU (Zakia, 2020).

\section{Strategi Pengembangan Produk BPRS UMMU di Bangil Pasuruan}

PT. BPRS UMMU Bangil memiliki strategi yang disebut sebagai Account Officer Funding dan Account Officer Landing yaitu merupakan sebuah kegiatan menghimpun dana dan menyalurkan dana langsung dari nasabah. Account Officer yaitu sumber daya manusia yang diberikan kemampuan untuk membantu direksi dalam menjalankan program khususnya dalam bidang pemasaran dan pembiayaan (Jopie, 1997).

Account Officer di PT. BPRS UMMU Bangil dibedakan menjadi dua, yaitu Account Officer Funding dan Account Officer Landing. Seorang Account Officer Funding di PT BPRS UMMU mempunyai tugas untuk menghimpun setiap tabungan nasabah yang berada di pasar Bangil, Sedangkan Account Officer Landing tugasnya adalah menyalurkan dana kepada nasabah untuk melakukan pembiayaan dalam mengembangkan usahanya, baik yang memiliki usaha mikro, kecil dan menengah.

Dari hasil wawancara yang telah peneliti lakukan terhadap narasumber yang dimana disini adalah Ibu Yuli selaku Kepala Bagian Operasional Bank Pembiayaan 
Rakyat Syariah (BPRS) UMMU Bangil Pasuruan. Dalam penyaluran dana menawarkan produk pembiayaan konsumtif dan pembiayaan produktif serta modal kerja dengan prinsip akad Murabahah, Musyarakah dan Mudharabah. Akan tetapi, pembiayaan yang paling banyak diminati oleh nasabah adalah akad Murabahah. Hal ini berdasarkan data yang diperoleh dari Pak Badrus selaku bagian legal atau admin pembiayaan:

Tabel 2. Jumlah Pembiayaan Aktif s/d 2020

PT. BPRS UMMU Bangil Pasuruan

\begin{tabular}{|c|c|}
\hline Keterangan & Jumlah Nasabah \\
\hline Murabahah & 1.704 \\
\hline Musyarakah & 149 \\
\hline Mudharabah & 127 \\
\hline
\end{tabular}

Sumber: PT. BPRS UMMU Bangil Pasuruan

Selanjutnya, menurut hasil wawancara dengan Ibu Hikmah, dari produk-produk BPRS UMMU Bangil Pasuruan yang ada, 85\% pembiayaan yang digunakan adalah pembiayaan murabahah. Hal ini dikarenakan pembiayaan murabahah persyaratannya mudah dan tidak ribet. Sistem pembiayaan murabahah juga terbilang cukup sederhana. Hal ini memudahkan bank syariah dalam penanganan administrasinya (Antonio, 2001).

Menurut Pak Agus selaku marketing di PT. BPRS UMMU Bangil Pasuruan, yang membedakan PT. BPRS UMMU Bangil Pasuruan dengan bank syariah yang lain adalah pinjaman tanpa jaminan. Alasan diberlakukannya pinjaman tanpa jaminan ini karena persaingan yang ketat dengan pemberi pinjaman lain atau yang biasa disebut dengan bank plecit atau titil, yang memberikan pinjaman tanpa jaminan bahkan dapat cair ditempat. Akan tetapi tidak semua nasabah mendapatkan pinjaman tanpa jaminan, hanya beberapa nasabah saja, karena BPRS UMMU Bangil Pasuruan masih terikat dengan aturan bank. Hal ini membuat BPRS UMMU Bangil Pasuruan belajar dari pesaing seperti bank plecit atau titil untuk tetap mempertahankan dan mencari nasabah. Karena nasabah pasar dan warga sekitar lebih memilih bank yang dalam pencairan dana tidak menyulitkan nasabah.

Berdasarkan dari hasil wawancara Petugas atau Pimpinan PT. BPRS UMMU Bangil Pasuruan ini, dapat disimpulkan bahwasanya strategi pengembangan produk P-ISSN : 2460-9595

E-ISSN : 2686-5149

DOI. 10.36908/isbank 


\section{2 | Nila Safira Ramadhanty, Renny Oktafia, STRATEGI PENGEMBANGAN PRODUK..........}

pembiayaan dalam upaya peningkatan kapasitas UMKM pada BPRS UMMU di Bangil Pasuruan yang pertama adalah dengan cara memberikan suatu pinjaman kepada nasabah tanpa jaminan, hal ini dapat menarik minat nasabah agar melakukan pembiayaan pada BPRS UMMU di Bangil Pasuruan tersebut.

Strategi yang kedua yaitu, Petugas yang bekerja di bagian marketing yang disebut sebagai Account Officer Landing yang bertugas untuk menyalurkan dana juga terjun langsung dalam memberikan pembiayaan dana/uang kepada nasabah serta mengambil angsuran nasabah yang mempunyai tanggungan untuk mengangsur pembiayaannya tersebut agar memudahkan serta meringankan nasabah dalam pengembangan usahanya, dan nasabah tidak perlu datang ke Kantor BPRS UMMU di Bangil Pasuruan.

\section{Dampak Strategi Pengembangan Produk Pembiayaan Dalam Upaya Peningkatan Kapasitas UMKM BPRS Ummu Di Bangil Pasuruan}

Hasil dari wawancara dengan PT. BPRS UMMU di Bangil Pasuruan menyatakan bahwa adanya peningkatan pembiayaan kepada UMKM yang cukup signifikan di tahun 2019. PT BPRS UMMU di Bangil merupakan lembaga keuangan syariah yang memiliki peran yang cukup penting dalam upaya peningkatan kapasitas UMKM yaitu berupa pemberian 3 produk pembiayaan kepada nasabah berupa Murabahah (modal kerja), Mudharabah (bagi hasil) dan Musyarakah (penyertaan). Murabahah menjadi salah satu produk yang sangat diminati oleh nasabah, mengingat bahwa modal kerja sangat diperlukan dalam berbisnis atau melakukan suatu usaha terlebih bagi para pemula UMKM yang sangat membutuhkan modal dalam pengembangan usahanya. Hal ini berdampak pada roda perekonomian di ruang lingkup UMKM di Bangil Pasuruan.

Pada praktiknya, PT. BPRS UMMU di Bangil Pasuruan menerapkan sistem ekonomi Islam kepada nasabah UMKM di Bangil, mengingat bahwa banyaknya pemberian modal melalui rentenir yang bisa berdampak kepada transaksi yang mengandung riba. Oleh karena itu PT. BPRS UMMU di Bangil Pasuruan memberikan alternatif positif kepada nasabah UMKM agar melakukan transaksi maupun pembiayaan yang di dalamnya tidak mengandung riba, sebagaimana praktik yang dilakukan PT. BPRS UMMU di Bangil Pasuruan tersebut. Dengan demikian terdapat dampak positif 
ISLAMIC BANKING: Jurnal Pemikiran dan Pengembangan Perbankan Syariah, Volume 6 Nomor 2 Edisi Februari 2021

bagi PT. BPRS UMMU di Bangil Pasuruan dalam upaya peningkatan kapasitas UMKM.

PT. BPRS UMMU di Bangil Pasuruan telah memberikan peran dalam membantu para pelaku usaha dalam pemberian pembiayaan modal, karena dalam berbisnis harus ada modal yang cukup agar bisnis atau kegiatan usahanya dapat berjalan dengan baik serta nasabah dapat menjalankan serta mengembangkan usahanya, baik nasabah yang baru memulai dalam merintis usaha maupun nasabah yang sudah lama memulai sebuah usahanya tanpa adanya halangan dalam urusan permodalan. Dan salah satu tujuan utama PT. BPRS UMMU di Bangil Pasuruan itu sendiri agar tercapainya suatu tujuan yaitu tercukupinya modal para nasabah yang menjalankan kegiatan usahanya guna meningkatkan kapasitas usaha mikro, kecil maupun menengah.

\section{Simpulan}

BPRS UMMU Bangil hadir ditengah-tengah masyarakat dalam rangka ikut serta dalam membantu dan memudahkan korelasi antara pemodal dan peminjam. Didalam sistem yang dibangun oleh BPRS UMMU Bangil adalah asas kepercayaan dan amanah. Sehingga bisa diharapkan agar terjadi sebuah peningkatan disektor perekonomian yang dimulai dari tingkat Usaha Mikro Kecil dan Menengah. Dalam hal ini BPRS UMMU telah meluncurkan berbagai strategi agar menarik para nasabah untuk bergabung dalam operasional, strategi yang sudah diluncurkan seperti memberikan pinjaman tanpa mengambil jaminan kepada para nasabah, nasabah tidak perlu mendatangi kantor BPRS dalam hal pengembalian pinjaman karena pihak marketing BPRS yang akan mengambil nya kepada para nasabah, hal ini diharapkan bisa memudahkan dan mempercepat kinerja nasabah tanpa harus bersusah payah meninggalkan pekerjaannya.

Dampak bagi nasabah yang memiliki usaha mikro, kecil maupun menengah (UMKM) dengan melakukan pembiayaan pada BPRS UMMU di Bangil Pasuruan tersebut. Nasabah menjadi mudah dan tidak perlu lagi mencari modal usaha dengan susah payah, cukup mendatangi BPRS UMMU di Bangil Pasuruan untuk melakukan pembiayaan dengan syarat-syarat yang sangat mudah. 


\section{DAFTAR PUSTAKA}

Al-Qur'an. (2019). Departemen Agama Republik Indonesia. quran.kemenag.go.id.

Antonio, M. S. (2001). Bank Syariah dari Teori ke Praktek. Gama Insani Press.

Darsono. (2017). Perbankan Syariah di Indonesia: Kelembagaan dan Kebijakan Serta Tantangan ke Depan. Rajawali Press.

Haris, D. (2017). Pengelolaan dan Pengembangan Produk Baru. PT Gramedia Pustaka Utama.

Havis Aravik, A. I. H. (2021). Etika Perbankan Syariah: Teori dan Implementasi. Deepublish.

Iska, S. (2012). Sistem Perbankan Syariah di Indonesia Dalam Perspektif Fikih Ekonomi. Fajar Media Press.

Jopie, J. (1997). Panduan Dasar untuk Account Officer. Akademi Manajemen Perusahaan YKPN.

Moelong, J. L. (2016). Metode Penelitian Kualitatif. PT Remaja Rosdakarya.

Musfiqon. (2012). Metodologi penelitian Pendidikan. Prestasi Pustaka.

Partono, T. S., \& Soejono, A. R. (2002). Ekonomi Skala Kecil dan Kecil Menengah dan Koperasi. Galia Indonesia.

Rangkuti, F. (1997). Analisis SWOT: Teknik Membedah Kasus Bisnis. PT Gramedia Pustaka Utama.

Soemitra, A. (2016). Bank dan Lembaga Keuangan Syariah. Kencana.

Sugiyono. (2018). Metode Penelitian Kuantitatif Kualitatif dan $R \& D$ (27th ed.). Alfabeta.

Suharsaputra, U. (2014). Metode Penelitian Kuantitatif, Kualitatif, Dan Tindakan. Refika Aditama.

Susanto, A. (2008). Sistem Informasi Akuntansi. Gramedia.

Syahreni, S. R. (2014). Perbankan Syariah: Produk-produk dan Aspek Hukumnya. Kencana.

Tjiptono. (2017). Pemasaran Strategik (2nd ed.). Andi.

Umar, H. (2008). Metode Penelitian untuk Skripsi dan Tesis Bisnis. PT Raja Grafindo Persada.

Wiroso. (2005). Jual Beli Murabahah (1st ed.). UII Press.

Zakia, E. K. (2020). Analisis Penerapan Manajemen Resiko Pada Pembiayaan Murabahah Di PT. BPRS UMMU Bangil Pasuruan. 52. 